\title{
Determination of Equilibrium Constant at Supercritical Carbon Dioxide Condition for Pithecellobium Jiringan (Jack) Prain Seeds.
}

\author{
Mohd Azizi Che Yunus, Nur Husnina Arsad, Zuhaili Idham
}

\begin{abstract}
Pithecellobium Jiringan (Jack) Prain (P.Jiringan) is one of the medicinal plant sources that consist of antioxidant compounds. The aim of this study was to investigate the effects of supercritical carbon dioxide $\left(\mathrm{SC}-\mathrm{CO}_{2}\right)$ extraction parameters on solubility and to determine the equilibrium constant of P.Jiringan oil in $\mathrm{SC}-\mathrm{CO}_{2}$ and correlated the data with Chrastil and del Valle \& Aguilera models. The experimental were conducted at temperatures ranging from $40^{\circ} \mathrm{C}$ to $70^{\circ} \mathrm{C}$ and pressure from $27.58 \mathrm{MPa}$ to 44.82 MPa. The extraction duration was 60 minutes. The result shows the solubility of oil increased as the density of $\mathrm{CO}_{2}$ increased at constant temperature. The solubility experimental data correlated with both model was good agreement with more that 95\% similarity where the Chrastil model was the best model correlated with the experimental data since the AARD\% of Chrastil model (0.206\%) is lowest compared to AARD\% of del Valle and Aguilera model (0.5818). In addition, $\mathrm{SC}-\mathrm{CO}_{2}$ give the highest oil yields compared to accelerated solvent extraction (ASE) and soxhlet extraction process.
\end{abstract}

Keywords: Equilibrium constant, Chrastil's model, Pithecellobium Jiringan (Jack) Prain, Solubility, Supercritical fluid extraction

\section{Introduction}

Supercritical carbon dioxide extraction $\left(\mathrm{SC}-\mathrm{CO}_{2}\right)$ is the most commonly use for supercritical fluid extraction (SFE) application because of its moderate critical temperature and pressure of $31^{\circ}$ and $7.38 \mathrm{MPa}$ SFE is known to be dependent on the density of the fluid that in turn can be manipulated through control of the system pressure and temperature. The dissolving power of a SFE increases with isothermal increase in density.

The basic principle of SFE is that the solubility of a interest solute in a solvent varies with both temperature and pressure. At ambient conditions $\left(25{ }^{\circ} \mathrm{C}\right.$ and 1 bar $)$ the solubility of a solute in a gas is usually related directly to the vapor pressure of the solute and is generally negligible. Moreover, one of the main advantages of supercritical fluids is the ability to modify their selectivity by varying the pressure and temperature (modify fluid density). Therefore, supercritical fluids are often used to extract selectively or separate specific compounds from a mixture. On the other hand, accelerated solvent extraction (ASE) and soxhlet extraction were used to make a comparison with $\mathrm{SC}-\mathrm{CO}_{2}$ on the global oil yield. The comparison was study to determine the best process to extract oil from P.Jiringan seeds.

Mohd Azizi Che Yunus, Nur Husnina Arsad and Zuhaili Idham Centre of Lipid Engineering and Applied Research, Faculty of Chemical Engineering, Universiti Teknologi Malaysia,

Country: Malaysi
Malaysia has about 12,000 species of plants of which about 1,300 are said to be medicinal and only a small number of these plants have been fully investigated for their potential [1]. One of them is Pithecellobium Jiringan (Jack) Prain (P.Jiringan). The beans are commercially available in markets during most of the year and even though the P.Jiringan seeds, it is rich in essential compounds including protein, carbohydrates, fiber, calcium, phosphorus, vitamins and sterols which make it possible to be developed into medicinal drugs especially for anti-diabetics and anti-hypertension $[2,3]$.

Solubility measurement can be obtained both experimental and modeling. It is important to obtain the solubility of solutes in the $\mathrm{SC}-\mathrm{CO}_{2}$ extraction in order to determine the optimal operating conditions. Moreover, the solubility model also very significant in up scaling process. Most models can be classified as being either semi-empirical or equation-of-state based. However, semi-empirical models are often utilized because their relative ease of application equated to equations of state. The most common semi-empirical models are established upon providing a correlation between solubility and density; hence, they are referred to as density-based models. The most common semi-empirical methods are those developed by Chrastil [4]. This study, focus more on correlating the solubility of some compounds in $\mathrm{SC}-\mathrm{CO}_{2}$ using the Chrastil's model and del Valle and Aguilera model [5]. The aim of this study was to investigate the effects of extraction conditions namely, pressure and temperature especially on the solubility of P.Jiringan oil in $\mathrm{SC}-\mathrm{CO}_{2}$, besides extraction yield. Furthermore, the correlation of experimental solubility data correlated with Chrastil and del Valle and Aguilera models were in this study.

\section{Materials and Methods}

\section{A Sample Preparation}

Matured and fresh P.Jiringan seeds were used and obtained from a local market at Taman Universiti, Skudai, Malaysia. Seeds was separated from fruits and thoroughly washed with tap water followed by distilled water. Next, the seeds were cut into small pieces $(2-3 \mathrm{~cm}$ diameter and $1 \mathrm{~mm}$ thickness) and were sun-dry conventionally all day long. P.Jiringan seeds were finely ground achieved powder form. The particle size was determined by sieving and was fixed at $215 \mu \mathrm{m}$. $215 \mu \mathrm{m}$ was the best particle size to obtain the maximum yield [2]. 


\section{B Supercritical Carbon Dioxide System}

Supercritical fluid extraction was performed using SFX TM 220 extraction system (ISCO, Lincoln, NE, US) consisting of high pressure syringe pump (Model: 100DX), extractor chamber, $2.5 \mathrm{~mL}$ stainless steel extraction cell and extractor controller (Model: SFX 200) was used in this study. Others part involved were a chiller (Model: Yih Der BL-730). $\mathrm{CO}_{2}$ with $99.99 \%$ purity (MOX Gases Sdn. Bhd. Selangor) was used as a solvent throughout the process.

The ranges of parameters were presented in Table 1. On the other hand, the fixed parameters for particle size, mass of sample, flow rate and extraction time were $215 \mu \mathrm{m}, 2.0 \mathrm{~g}, 2.2$ $\mathrm{mL} / \mathrm{min}$ and 60 minutes respectively.

TABLE 1 Range of process parameter applied in extraction process

\begin{tabular}{|c|c|c|c|c|}
\hline $\begin{array}{l}\text { Process } \\
\text { Parameter }\end{array}$ & Unit & Range & $\begin{array}{l}\text { Increme } \\
\text { nt }(\Delta)\end{array}$ & Responses \\
\hline $\begin{array}{l}\text { Temperature, } \\
\mathrm{T}\end{array}$ & ${ }^{\circ} \mathrm{C}$ & $\begin{array}{l}40.00 \leq \mathrm{T} \leq \\
70.00\end{array}$ & $\begin{array}{l}\Delta \mathrm{T}= \\
10.00\end{array}$ & \multirow{2}{*}{ Solubility } \\
\hline Pressure, $\mathrm{P}$ & $\mathrm{MPa}$ & $\begin{array}{l}27.58 \leq \mathrm{P} \leq \\
44.82\end{array}$ & $3.45^{\Delta \mathrm{P}}=$ & \\
\hline
\end{tabular}

\section{Soxhlet Extraction}

Soxhlet extractions were performed using $15 \mathrm{~g}$ weighed of powdered P.Jiringan seeds and were placed in a thimble holder. Soxhlet extraction was carried out using $300 \mathrm{~mL}$ of solvents (Hexane and Water). The extraction time was performed in 6 hours.

\section{Accelerated Solvent Extraction (ASE)}

$10 \mathrm{~g}$ of grounded $P$. Jiringan seeds were extracted using ASE 150 system (Dionex, Sunnyvale, CA, USA) with hexane as a solvent. Extractions were performed at three different parameters which are temperatures $\left(70,90\right.$ and $\left.110{ }^{\circ} \mathrm{C}\right)$, extraction times (5, 10 and 15 minutes) and cycles $(1,2$ and 3). Sample mixed homogeneously with $5 \mathrm{~g}$ weight of diatomaceous earth was loaded into $34 \mathrm{~mL}$ stainless-steel extraction cells and filled with solvent up to a pressure of 1500 psi.

\section{E Solubility of P.Jiringan oil in $\mathrm{SC}-\mathrm{CO}_{2}$}

In the experimental work, the solubility data of P.Jiringan oil in supercritical $\mathrm{CO}_{2}$ for temperatures ranges from $40{ }^{\circ} \mathrm{C}$ to $70{ }^{\circ} \mathrm{C}$ and pressures ranges from $27.58 \mathrm{MPa}$ to $44.82 \mathrm{MPa}$ were measured by plotting experimental data of mass of oil extracted against the mass of $\mathrm{CO}_{2}$ used (overall extraction curves). The curves were developed at $2.2 \mathrm{~mL} / \mathrm{min}$ of $\mathrm{CO}_{2}$ flow rate. Therefore, the solubility $\left(\mathrm{y}^{*}\right)$ was the slope of the constant extraction rate period of the overall extraction curves. Chrastil and Del Vale \& Aguilera models were selected to evaluate the use of empirical model to correlate solubility data of P.Jiringan oil in supercritical $\mathrm{CO}_{2}$. These models are described to be appropriate for the range of temperature and pressure from which the experimental values were obtained.

A multilinear regression was performed by using Solver in Excel 2007 program to determine the model constants. The accuracy of Chrastil models and del Valle and Aguilera model were quantified by analysis of average absolute relative deviation percentage (AARD). Equation 1 represents the method in calculating AARD\%.

$$
\mathrm{AARD} \%=\frac{1}{n} \sum_{i=1}^{n}\left|\frac{y_{i, \exp }-y_{i, \text { calc }}}{y_{i, \exp }}\right| \times 100
$$

Where $\mathrm{n}=$ number of data

$\mathrm{Y}_{\mathrm{i}, \mathrm{exp}} \quad=$ solubility data obtained from experimental respectively at $i^{\text {th }}$ condition

$\mathrm{Y}_{\mathrm{i}, \text { calc }}=$ solubility data obtained from Chrastil model respectively at $i^{\text {th }}$ condition

\section{F Chrastil Model}

The Chrastil's model studies the formation of a solvation complex between the solvent and the solute molecules in the equilibrium, establishing a linear relation between solubility, solvent density and process temperature. The equation that represents the solubility model derived by Chrastil showed as follows:

$$
Y^{*}=\rho^{k} \exp \left(\underset{\mathrm{T}}{\left(\_-a+b\right.}+b\right)
$$

Where $y^{*}=$ the solute solubility

$$
\begin{aligned}
& \mathrm{T}=\text { temperature }(\mathrm{K}) \\
& \rho=\text { solvent density }(\mathrm{g} / \mathrm{L})
\end{aligned}
$$

Meanwhile, for coefficient of $a$ and $b$ represents:

$$
\begin{aligned}
a= & \frac{\Delta H}{R T} \\
b= & \ln \left(M_{A}+k M_{B}\right)+q-k \ln M_{B}
\end{aligned}
$$

Where; $\quad \Delta H=\Delta H_{\text {solv }}+\Delta H_{\text {vap }}$ and $q=q_{s}+q_{v}$

$M_{A}=$ molecular weights of the solute

$M_{B}=$ molecular weights of the gas

Also, $a, b$ and $k$ represent the adjustable constants of the model. The constant $k$ indicates the number of $\mathrm{CO}_{2}$ molecules present in the complex solute-solvent (equilibrium constant). The $a$ and $b$ parameters are vaporizing enthalpy and molecular weight dependants, respectively.

\section{G Del Valle \& Aguilera's Model}

The del Valle and Aguilera model is a modification of the Chrastil model. The equation of del Valle and Aguilera model can be expressed as follows:

$$
\ln Y^{*}=k \ln \rho+\frac{a}{\mathrm{~T}}+\frac{b}{\mathrm{~T}^{2}}+c
$$




\section{Results and Discussion}

\section{A Solubility of P.Jiringan Oil in $\mathrm{SC}-\mathrm{CO}_{2}$}

The solubility of P.Jiringan oil in $\mathrm{SC}-\mathrm{CO}_{2}$ was evaluated at temperatures ranging from $40{ }^{\circ} \mathrm{C}$ to $70{ }^{\circ} \mathrm{C}$ and pressures ranging from $27.58 \mathrm{MPa}$ to $44.82 \mathrm{MPa}$. The solubility data was obtained using a dynamic method and overall extraction curves were plotted as mass of carbon dioxide used versus mass of oil extracted. The solubility data for each condition were obtained from the slope of the linear portion of the overall extraction curve.

Figure 1 shows the effects of pressure and temperature on the solubility of P.Jiringan oil in SC- $\mathrm{CO}_{2}$. The result shows that at constant temperature, the solubility of oil increased as the density of $\mathrm{CO}_{2}$ increased. Meanwhile, at constant pressure, the solubility of oil increased as the temperature increased even though the density of $\mathrm{CO}_{2}$ decreased. From the observation, it showed that as the pressure increased from $27.58 \mathrm{MPa}$ to $31.03 \mathrm{MPa}$, the solubility increased drastically at temperature $60{ }^{\circ} \mathrm{C}$ and $70{ }^{\circ} \mathrm{C}$. However, the solubility was slightly increased at the temperatures of $40{ }^{\circ} \mathrm{C}$ and $50{ }^{\circ} \mathrm{C}$. This was due to the competing effect which the increase of vapor pressure was more dominant than the decrease of $\mathrm{CO}_{2}$ density.

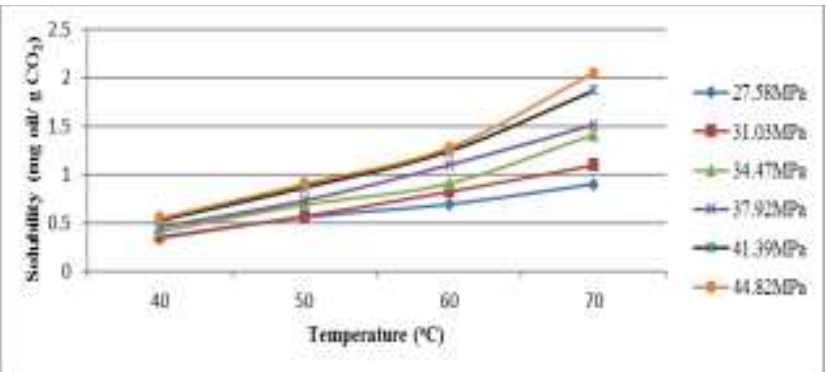

Figure 1 P.Jiringan oil solubility as a function of temperature at different pressure

A similar result studied on the effects of pressure and temperature on the solubility of P.Jiringan oil in $\mathrm{SC}-\mathrm{CO}_{2}$ had been reported [2]. The parameters used in his study were pressures at the range of $20.68 \mathrm{MPa}$ to $55.15 \mathrm{MPa}$ and temperatures at $40{ }^{\circ} \mathrm{C}, 50{ }^{\circ} \mathrm{C}, 60{ }^{\circ} \mathrm{C}, 70{ }^{\circ} \mathrm{C}$ and $80{ }^{\circ} \mathrm{C}$. The resulted show that the solubility increased as the temperature increased at a constant pressure. Moreover, the solubility effect as a function of pressure was less significant compared to the solubility effect as a function of temperature. The solubility in his study increased from 1.10 to $2.60 \mathrm{mg}$ oil per g $\mathrm{CO}_{2}$ at the constant pressure of $55.15 \mathrm{MPa}$ as the temperature increased from $40{ }^{\circ} \mathrm{C}$ to $80{ }^{\circ} \mathrm{C}$. It shows that the effect of temperature was more dominant than the pressure.

This trend was similarly reported by Ana Najwa [6] findings which showed the increment of solubility where the increase in pressure was slower than as the increase in temperature. Besides that, the solubility of palm oil in R134a at $60{ }^{\circ} \mathrm{C}$ and $80^{\circ} \mathrm{C}$ suddenly increased from 45 to 60 bar. This is due to the balancing between the increase in the solute vapor pressure and the decrease in solvent density which is known as competing effect. This phenomenon occurred at the lowest and the highest temperature. In her study, she assumed that the solute vapor pressure played a major role in increasing the oil solubility and she concluded that temperature had a dominant effect on palm oil solubility.

The solubility data of P.jiringan oil in $\mathrm{SC}-\mathrm{CO}_{2}$ in this study were correlated with models proposed by Chrastil (Equation 2) and by Del Valle and Aguilera (Equation 3). Figure 2 shows the correlation of solubility experimental data of P.Jiringan oil solubility in $\mathrm{SC}-\mathrm{CO}_{2}$ by chrastil model and by del Valle and Aguilera model.

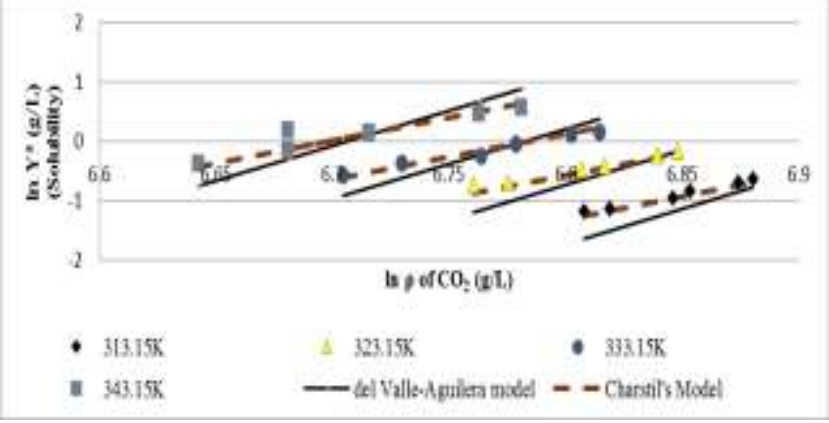

Figure 2 Correlation of $P$.Jiringan oil solubility in $\mathrm{SC}-\mathrm{CO}_{2}$ experimental data with Chrastil and del Valle-Aguilera model.

In this analysis, the experimental data was accommodated with both models to obtain the parameters involved. The parameters of Chrastil's model ( $a, b$ and $k$ ) and del Valle and Aguilera model $(a, b, c$ and $k$ ) were determined by minimizing the objective function (Equation 1) which was known as average absolute relative deviation percentage (AARD\%) using Solver in Excel 2007 program.

In Chrastil's model, the parameters obtained represent the important term. For parameter $a$, it represents the heat of salvation and vaporization of the solute, meanwhile parameter $b$ represents the molecular weight and melting point of solute involved and $k$ represents the average number of molecules that form the solvate-complex which is also known as equilibrium constant. From the analysis of the results, the AARD\% of correlation between the solubility experimental data with the Chrastil's model obtained was $0.206 \%$.

Moreover, in del Valle and Aguilera model, the parameters used were the same as Chrastil's model and $c$ was the additional constant for the model. The analysis was done by minimizing the AARD\% and directly determined the constant parameters which were $a, b, c$ and $k$ in the equation. The results from the analysis show that the AARD\% of correlation between the solubility experimental data with the del Valle and Aguilera model obtained was $0.5818 \%$.

Constant parameter of $a$ showed the influence of the temperature change inside the extraction vessel. According to Maria Salud [7] as an absolute value of parameter $a$ is high, it relates with high temperature influence. Moreover, they said that lower $k$ value indicates that most of the oil was extracted with $\mathrm{SC}-\mathrm{CO}_{2}$ from the sample itself. Meanwhile, constant parameter $b$ indicates that the solute had been extracted. In addition, according to Wahyu B. Sentianto [8], parameter $k$ and $b$ can be assumed as parameters that are independent of temperature. Following this, the solubility parameters $a$, b, $c$ and $k$ of Chrastil and del Valle-Aguilera model calculated are shown in Table 2. 
TABLE II Coefficient parameter and AARD\% for Chrastil and del ValleAguilera model

\begin{tabular}{|l|c|c|c|c|l|}
\hline \multirow{2}{*}{ Model } & \multicolumn{3}{|c|}{ Model Coefficient } & $\begin{array}{l}\text { Average } \\
\text { absolute } \\
\text { relative } \\
\text { deviation } \\
\text { percentag } \\
\text { e(AARD } \\
\%)\end{array}$ \\
\cline { 2 - 6 } & $\boldsymbol{a}$ & $\boldsymbol{b}$ & $\boldsymbol{c}$ & $\boldsymbol{k}$ & \\
\hline Chrastil & -7549.77 & -29.9029 & - & 7.74925 & 0.206 \\
\hline $\begin{array}{l}\text { Del } \\
\text { Valle- } \\
\text { Aguilera }\end{array}$ & -10001.2 & -20000 & -49.7187 & 11.7845 & 0.5818 \\
\hline
\end{tabular}

Previous researchers had reported the solubility correlation by Chrastil's model and by del Valle and Aguilera model in literature. The Chrastil model and del Valle-Aguilera model were used to correlate solubility data of virgin coconut oil (VCO) in $\mathrm{CO}_{2}$ at temperature ranges of $40{ }^{\circ} \mathrm{C}$ to $80{ }^{\circ} \mathrm{C}$ and pressure ranges of $20.7 \mathrm{MPa}$ to $34.5 \mathrm{MPa}$. The result shows that AARD\% of del Valle and Aguilera model obtained was $0.39 \%$ meanwhile, AARD\% of Chrastil model obtained was $0.93 \%$. Even though both models gave good correlation of the data, he conclude that del Valle and Aguilera model as the best model correlated with the experimental data since the AARD\% of del Valle and Aguilera model is lowest compared to AARD\% of chrastil model [9].

The results show that most of the data obtained from Chrastil model approaching nearly to the solubility of experimental data compared to data obtained from del Valle and Aguilera model. Therefore, it shows that the Chrastil model was successful matched to the solubility experimental data compared to del Valle and Aguilera model.

In addition, the value of AARD\% of Chrastil's and del Valle and Aguilera models was used as a comparison. The result of AARD\% calculated for Chrastil model and del Valle and Aguilera model are shown in Table 3. The AARD\% from del Valle-Aguilera model was poor compared to the value from Chrastil model. The best model that fitted the experimental data was obtained by Chrastil model (Equation 2) with the smallest AARD\% value.

\section{B Comparison of the $\mathrm{SC}-\mathrm{CO}_{2}$ Extraction with ASE and Hexane Soxhlet Extraction}

An overall extracted oil yield obtained from the various condition of $\mathrm{SC}-\mathrm{CO}_{2}$ was compared with those obtained from different methods of extraction, hexane soxhlet extraction and ASE. The various condition of $\mathrm{SC}-\mathrm{CO}_{2}$ was selected at the higher conditions $\left(44.82 \mathrm{MPa}\right.$ and $70{ }^{\circ} \mathrm{C}$ ), low conditions (22.58 MPa and $40{ }^{\circ} \mathrm{C}$ ) and moderate conditions (37.92 MPa and $60{ }^{\circ} \mathrm{C}$ ) in order to compare the performance of $\mathrm{SC}-\mathrm{CO}_{2}$ method than others. The highest overall extraction oil yield is $4.49 \%$ with the $\mathrm{SC}-\mathrm{CO}_{2}$ at highest condition, followed by hexane soxhlet extraction yield of $3.97 \%$. Finally the lowest oil yield of $0.587 \%$ obtained from ASE, as presented in Figure 3. The $\mathrm{SC}-\mathrm{CO}_{2}$ conditions at $44.82 \mathrm{MPa}$ and $70{ }^{\circ} \mathrm{C}$ was generated higher oil yield than other extraction mediums. This is because high oil solubilization capability than hexane soxhlet and ASE as well as capable to extract the groups of oleo resin and waxes (typically waxy materials in the outer part of the seed). According to Taylor [10] in the Stahl's extraction rules with pure $\mathrm{CO}_{2}$, the more strongly polar (e.g amino acid) only could be extracted in the range above 40.00 $\mathrm{MPa}$. Therefore, at the higher $\mathrm{SC}-\mathrm{CO}_{2}$ extraction conditions, $\mathrm{CO}_{2}$ solvent was able to extract both, the polar and non-polar compounds.

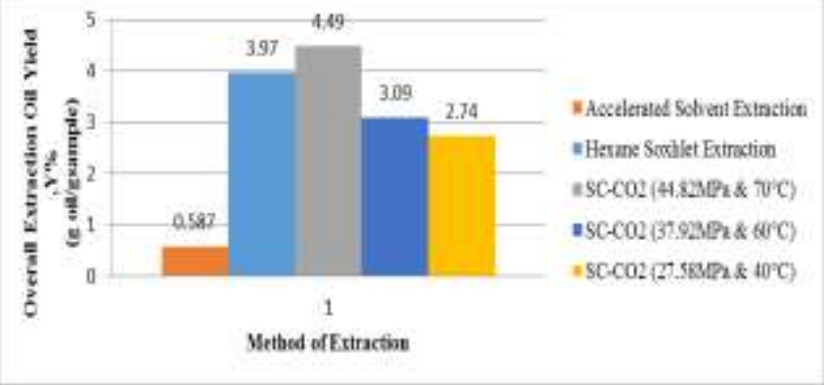

Figure 3 Comparison of an overall extraction oil yield obtained from different conditions of $\mathrm{SC} \mathrm{CO}_{2}$ with Hexane Soxhlet and ASE

\section{Conclusion}

The extraction of P.Jiringan seeds using supercritical carbon dioxide extraction was performed at temperatures ranging from $40^{\circ} \mathrm{C}$ to $70^{\circ} \mathrm{C}$ and pressures ranging from $27.58 \mathrm{MPa}$ to $44.82 \mathrm{MPa}$. The solubility of $P$. Jiringan oil in supercritical carbon dioxide was measured from the slope of the linear portion of the overall extraction curve. The results show that at constant temperature, the solubility of P.Jiringan oil increased as the density of $\mathrm{CO}_{2}$ increased. In the meantime, at constant pressure, the solubility of oil increased as the temperature increased even though the density of $\mathrm{CO}_{2}$ decreased. The maximum solubility of P.Jiringan oil was $2.0462 \mathrm{mg}$ oil per $\mathrm{g}$ of $\mathrm{CO}_{2}$ obtained at the temperature of $70^{\circ} \mathrm{C}$ and the pressure of $44.82 \mathrm{MPa}$. On the other hand, the minimum solubility of P.Jiringan oil was $0.3394 \mathrm{mg}$ oil per g of $\mathrm{CO}_{2}$ obtained at the lowest supercritical condition which was at the temperature of $40^{\circ} \mathrm{C}$ and the pressure of $27.58 \mathrm{MPa}$.

The experimental solubility data was correlated with two different empirical equations proposed correspondingly by Chrastil and del Valle and Aguilera. The lowest deviation between the experimental data and correlated values was obtained from the results taken at $60^{\circ} \mathrm{C}$ and $37.92 \mathrm{MPa}$ using the Chrastil model. From the observation, the solubility data were successfully fitted to the Chrastil model compared to del Valle and Aguilera model based on the AARD\% value. The AARD \% of Chrastil model which was $0.206 \%$ was lower than AARD\% of del Valle and Aguilera model which was $0.5818 \%$. In conclusion, the equilibrium constant for P.Jiringan seeds obtained was 7.74925 . 
Acknowledgement: This work was supported by the National Research Grant Scheme (NRGSR.J130000.7944.4H014), Malaysian Government and Universiti Teknologi Malaysia.

\section{References}

[1] Burkill I.H. 1935. A dictionnary of the economic products of the Malay peninsula. Edited by: Ministry of agriculture (Malaysia). Crown Agents for the Colonies. London. 839.

[2] Mohd Azizi Bin Che Yunus (2007). Extraction, Identification And Separation Of Vitamin E and Djenkolic Acid From Pithecellobium Jiringan (Jack) Prain Seeds Using Supercritical Carbon Dioxide. Doctor Philosophy, Universiti Sains Malaysia, Penang.

[3] Vimala, S., Abdul Rashid, A., Mohd Ilham, A. and Rohana, S. (2003). Nature's Choiceto Wellness Antioxidant Vegetables/Ulam, (Vol. 7). Kepong, Kuala Lumpur: Forest Research Institute of Malaysia.

[4] Chrastil, J. (1982). Solubility of Solids and Liquids in Supercritical Gases. The Journal of Physical Chemistry, 86, 3016-3021.

[5] Del Valle, J. M. and Aguilera, J. M. (1988). An improved equation for predicting the solubility of vegetable oil in supercritical $\mathrm{CO}_{2}$. Industrial Engineering Chemical Research, 27, 1551-1553.

[6] Ana Najwa Mustapa (2008). Extraction of Palm Oil Mesocarp Using Sub-Critical R134a. Master Degree, Universiti Teknologi Malaysia, Skudai.

[7] Maria, S. G. P., Maria, L. R. d. C., Gema, F. Guillermo S. M. and Gracia, P. B. (2007). Application of Chrastil's model to the extraction in SC-CO2 OF $\beta$-carotene and lutein in Mentha spicata L. The Journal of Supercritical Fluids, 43, 32-36.

[8] Wahyu, B. S., Nik Norulaini, N. A. R., Mohd Azizi, C.Y. and Mohd Omar, A. K. (2007). Medium-Chain Triglycerides rich oil extraction using supercritical carbon dioxide. International Conference on Chemical Sciences (ICCS-2007). 24-26 May. Yogyakarta, Indonesia, ANL/17-2.

[9] Wahyu Bahari Setianto (2010). Extraction and Solubility Studies of Medium Chain Triglycerides from Coconut (Cocos nucifera) Flesh using Supercritical Carbon Dioxide. Doctor Philosophy, Universiti Sains Malaysia, Penang.

[10] Taylor, T. L. (1996). Supercritical Fluid Extraction: Technique in Analytical Chemistry. New York: Wiley-Interscience.

[11] Azevedo, A.B.A., Kopcak, U,. and Mohamed, R.S. (2003). Extraction of fat from fermented Cupuaçu seeds with supercritical solvents. Journal of Supercritical Fluids, 27, 223-237.

[12] Westerman, D., Santos, R.C.D., Bosley, J.A., Rogers J.S. and Al-Duri, B. (2006). Extraction of Amaranth seed oil by supercritical carbon dioxide. The Journal of Supercritical Fluids, 37, 38-52.

[13] Soares, B. M. C., Gamarra, F. M. C., Paviani, L. C., Goncalves, L. A. G. and Cabral, F. A. (2007). Solubility of triacylglycerols in supercritical carbon dioxide. The Journal of Supercritical Fluids, 43, 25-31.

[14] Po-Yen, C., Wei-Heng, C., Shih-Ming, L. and Chieh-Ming, J. C. (2011). Solubility of Jatropha and Aquilaria oils in supercritical carbon dioxide at elevated pressures. The Journal of Supercritical Fluids, 55, 893-897.

[15] Ozkal, S. G., Salgın, U. and Yener, M. E. (2005). Supercritical carbon dioxide extraction of hazelnut oil. Journal of Food Engineering, 69, 217-223.

[16] Machmudah, S., Kawahito, Y., Sasaki, M. and Goto, M. (2007). Supercritical $\mathrm{CO}_{2}$ extraction of rosehip seed oil: Fatty acids composition and process optimization. The Journal of Supercritical Fluids, 41, 421428

[17] Stela, J., Sandra, S., Zoran, Z. and Senka, V. (2011). Mathematical modelling of soybean oil solubility in supercritical carbon dioxide. International Journal of Food Science and Technology, 46, 1031-1037.
About Author (s):

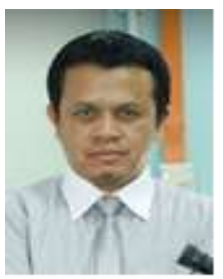

Mohd Azizi Che Yunus had received his B.Sc. (1988) and M.Sc. (2001) degree in Chemical Engineering from Universiti Teknologi Malaysia. He completed his Ph.D (2007) in Industrial Technology from Universiti Sains Malaysia.

$\mathrm{He}$ is an Assoc Professor in Chemical Engineering Department and also Director of Centre of CLEAR (Centre of Lipid Engineering Applied Research), UTM. His research interests are on extraction, separation and isolation of active compounds from local herbs. He is also specialist in method development of identification and validation of extracted compounds using chromatogram analysis.

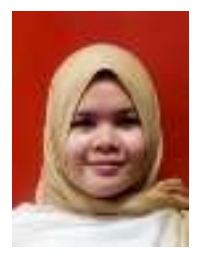

Nur Husnina Arsad had received her B.E (2009) and M.E (2012) in Chemical Engineering from Universiti Teknologi Malaysia.and currently pursuing her Ph.D in the same field at Universiti Teknologi Malaysia.

Her current research interests are in supercritical fluid extraction process, separation and also biotechnology.

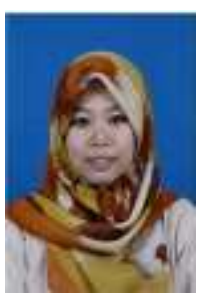

Zuhaili Idham had received her B.Sc in Biotechnology (2007) from University of Malaya and M.Sc from Universiti Teknologi Malaysia in Bioprocess Engineering. She is the research officer in Centre of Lipid Engineering and Applied Research (CLEAR), Universiti Teknologi Malaysia.

Her current research interest is in development of natural colourant/dyes from local Malaysian plants to be applied in food, cosmetics and textiles industry. 